\title{
RESPON PERTUMBUHAN DAN HASIL BAWANG PUTIH (Allium sativum L) DENGAN PEMBERIAN BERBAGAI MULSA PLASTIK
}

\author{
Gusni Yelni ${ }^{1}$, Rahman Sari ${ }^{2}$ \\ ${ }^{1}$ Program Studi Agroteknologi Fakultas Pertanian UMB \\ ${ }^{2}$ Alumni Program Studi Agroteknologi Fakultas Pertanian UMB
}

Artikel Diterima 8 Oktober 2020, disetujui 2 Desember 2020

\begin{abstract}
ABSTRAK
Penelitian dilaksanakan di kebun percobaan Fakultas Pertanian Universitas Muara Bungo Sungai Binjai KM 6 Kabupaten Bungo, dengan ketinggian $\pm 101 \mathrm{~m}$ dpl, dengan curah hujan 248,75 mm/bulan. Penelitian ini dilaksanakan pada tanggal 01 Mei 2019 sampai 14 Agustus 2019. Tujuan penelitian ini adalah untuk mengetahui pengaruh dan jenis mulsa plastik yang terbaik untuk pertumbuhan dan hasil bawang putih (Allium sativum L).

Penelitian ini menggunakan Rancangan Acak Kelompok (RAK) dengan 5 perlakuan dan 4 kelompok yaitu : M0 (Tanpa Mulsa), M1 (Mulsa plastik perak), M2 (Mulsa plastik hitam), M3 (Mulsa plastik transparan) dan M4 (Mulsa plastik biru). Variabel yang diamati yaitu tinggi tanaman $(\mathrm{cm})$, jumlah daun (helai), diameter umbi / tanaman $(\mathrm{cm})$, jumlah siung / umbi (siung), bobot basah umbi per rumpun (g), bobot basah umbi per petak (g) dan bobot kering umbi (ton/ha). Data dianalisis dengan menggunakan analisis ragam (anova). Apabila berpengaruh nyata maka dilanjutkan dengan uji Ducan Multiple Range Test (DMRT) pada taraf 5\%

Dari hasil penelitian diperoleh respon bawang putih terhadap variabel tinggi tanaman $(\mathrm{cm})$, jumlah daun (helai), diameter umbi/tanaman $(\mathrm{cm})$, bobot basah umbi perumpun $(\mathrm{g})$, bobot basah umbi perpetak (g) dan berat kering umbi (ton/ha) menunjukan respon yang berbeda sementara jumlah siung/umbi (siung) bawang putih memberikan respon tidak beda. Perlakuan M1 (Mulsa plastik perak) merupakan perlakuan terbaik terhadap pertumbuhan dan hasil bawang putih (Allium sativum L.).
\end{abstract}

\section{Kata kunci : Mulsa Plastik, bawang putih, Pertumbuhan dan Hasil}

\section{PENDAHULUAN}

Bawang putih (Allium sativum L.) mempunyai banyak manfaat, selain sebagai bumbu penyedap masakan, bawang putih juga memiliki banyak khasiat yang dapat menyembuhkan penyakit atau sebagai bahan obat-obatan untuk kesehatan manusia. Bawang putih juga memiliki potensi pasar yang tinggi, sebagai bahan perdagangan di dalam negeri maupun komoditas eksport. Hal tersebut memungkinkan karena bawang putih termasuk salah satu jajaran komoditas pertanian bernilai ekonomis tinggi (Wibowo, 2007).
Kebutuhan (konsumsi) bawang putih dari tahun ke tahun terus meningkat sejalan dengan meningkatnya jumlah penduduk dan semakin meningkatnya pengetahuan masyarakat akan pentingnya gizi komoditas tersebut. Namun, meningkatnya permintaan tersebut belum mampu diimbangi dengan peningkatan produksi. Hal ini disebabkan oleh luas tanam dan produktivitas hasil yang rendah (Rismunandar, 2003).

Dilihat dari segi produksi bawang putih di Indonesia pada tahun 2017 
mencapai 19.510 ton dengan luas panen 2.146 ha dan produktivitas 9,09 ton/ha, sedangkan di Provinsi Jambi, luas pertanaman bawang putih tidak terlalu luas yaitu hanya 1 ha dengan produktivitas hanya 0,20 ton/ha (Dirjen Hortikultura, 2018). Dan tidak ada data yang menunjukan produksi bawang putih di Kabupaten Bungo. Rendahnya produksi bawang putih ini mengharuskan pemerintah melakukan impor untuk memenuhi konsumsi komoditas tersebut (Wibowo, 2007 ; BPS, 2018).

Rendahnya produktivitas bawang putih di Provinsi Jambi dan tidak adanya produksi bawang putih di Kabupaten Bungo, karena kebanyakan varietas bawang putih hanya cocok ditanam di daerah dataran tinggi dan terbatasnya varietas bawang putih yang mempunyai daya adaptasi yang luas di dataran rendah (Sarwadana dan Gunadi, 2007). Sedangkan menurut Frona., dkk (2016), varietas bawang putih yang berkembang di Indonesia umumnya memiliki potensi hasil yang jauh lebih rendah dibandingkan dengan potensi hasil bawang putih di daerah subtropis. Hal ini disebabkan oleh keterbatasan dalam budidaya tanaman seperti media tanah yang digunakan, pengendalian hama, penyakit tanaman, gulma, pemupukan dan penanganan pasca panen.

Meningkatnya kebutuhan masyarakat akan tanaman bawang putih maka perlu dilakukan peningkatkan produksi tanaman bawang putih dan perluasan areal budidaya. Salah satu cara yang dapat dilakukan untuk meningkatkan produksi bawang putih adalah dengan memanipulasi lingkungan tumbuh seperti penggunaan mulsa. Mulsa adalah material penutup tanaman budidaya yang dimaksudkan untuk menjaga kelembaban tanah serta menekan pertumbuhan gulma dan penyakit sehingga membuat tanaman tumbuh dengan baik. Penggunaan mulsa plastik merupakan salah satu cara budidaya yang telah terbukti dapat meningkatkan hasil tanaman. Jenis mulsa plastik umumnya dibedakan berdasarkan warna dan intesitas cahaya yang dapat diteruskan, beberapa warna antara lain; bening/transparan, putih, perak, hitam, hitam perak, merah dan biru.

Plastik berwarna hitam dapat menghambat pertumbuhan gulma dan dapat menyerap panas matahari lebih banyak. Mulsa plastik bening/transparan dapat menciptakan efek rumah kaca, sementara mulsa plastik perak dapat memantulkan kembali sebagian panas yang diserap sehingga mengurangi serangan kutu daun (aphid) pada tanaman (Mawardi, 2000). Sedangkan mulsa plastik biru dapat meningkatkan kelembaban tanah lebih tinggi karena sifat fisik mulsa plastik biru (mpb) yang mampu meloloskan cahaya matahari (Jella., $d k k, 2017)$.

Adapun tujuan penelitian ini adalah untuk mengetahui pengaruh jenis mulsa plastik dan mendapatkan jenis mulsa plastik yang terbaik untuk pertumbuhan dan hasil bawang putih (Allium sativum $\mathrm{L}$ ).

Lamont dan Orzolek (2002)

dalam Prayoga (2016), melaporkan bahwa dari beberapa penelitian yang dilakukan pada berbagai sayuran menunjukan respon yang berbeda-beda terhadap warna mulsa tertentu. Warna mulsa plastik menentukan energy radiasi yang diterima, mempengaruhi iklim mikro di sekitar tanaman, dan secara spesifik warna mulsa plastik menentukan suhu udara di permukaan mulsa dan suhu tanah di bawah mulsa. Selain meningkatkan suhu tanah, mulsa plastik juga mampu menjaga kelembaban tanah, di sisi bawah plastik terbentuk banyak embun yang berguna untuk perbaikan pertumbuhan tanaman (Rahayu, 2017)

Penelitian tentang mulsa pada tanaman bawang putih belum ditemui 
namun penelitian mulsa pada tanaman berumbi lain seperti bawang merah menunjukan bahwa mulsa plastik perak menghasilkan pertambahan tinggi tanaman tertinggi dan panjang daun terpanjang pada umur 50 hari setelah tanam. Mulsa plastik hitam, mulsa plastik perak menghasilkan hasil lilit umbi bawang merah terbesar (Wisudawati., $d k k, 2016)$. Hasil penelitian Tinambunan (2014) menunjukkan bahwa penggunakan mulsa mampu memberikan pertumbuhan yang lebih baik serta meningkatkan produksi baby wortel daripada tanpa mulsa. Penggunaan mulsa plastik transparan menghasilkan menghasilkan bobot umbi segar panen yang lebih tinggi dibandingkan mulsa plastik hitam perak, mulsa plastik hitam, mulsa daun paitan, dan mulsa jerami padi perlakuan tanpa mulsa. Sedangkan penelitian Jella., $d k k$, (2017) menunjukan bahwa hasil umbi kentang dengan perlakuan mulsa plastik biru (mpb) tidak berbeda secara signifikan dengan penggunaan mulsa plastik hitam perak (mphp) pada umbi bibit $\mathrm{G} 2$.

Berdasarkan uraian di atas maka selayaknyalah dilakukan penelitian terhadap bawang putih sehingga penulis tertarik untuk melakukan penelitian dengan judul "Respon Pertumbuhan Dan Hasil Bawang Putih (Allium sativum L) Dengan Pemberian Berbagai Mulsa Plastik".

\section{METODE PENELITIAN}

Penelitian dilaksanakan di kebun percobaan Fakultas Pertanian Universitas Muara Bungo Sungai Binjai KM 6 Kabupaten Bungo, dengan ketinggian \pm $101 \mathrm{~m}$ dpl, dengan curah hujan 248,75 $\mathrm{mm} /$ bulan (Monografi Kelurahan Sungai Binjai, 2015). Penelitian ini dilaksanakan pada tanggal 01 Mei 2019 sampai 14 Agustus 2019. Bahan-bahan yang digunakan adalah bibit bawang putih varietas Sin Chung, dolomit, plastik perak, plastik hitam, plastik biru, plastik transparan, pupuk NPK $(15: 15: 15)$ dan pupuk kandang. Sedangkan alat - alat yang digunakan adalah timbangan digital, gembor, meteran, cangkul, label, handspayer, ember, ajir, buku data serta alat tulis untuk mencatat hasil pengamatan.

Penelitian ini menggunakan Rancangan Acak Kelompok (RAK) dengan 5 perlakuan dan 4 kelompok yaitu : M0 : Tanpa Mulsa, M1 : Mulsa plastik perak, M2 : Mulsa plastik hitam, M3 : Mulsa plastik transparan, dan M4

:Mulsa plastik biru. Masingmasing perlakuan diulang sebanyak 4 kali, sehingga diperoleh sebanyak 20 petak percobaan, jumlah tanaman tiap petak 80 tanaman, sehingga jumlah keseluruhan tanaman adalah $20 \times 80=$ 1600 tanaman, dengan jarak antar petak 30 x $30 \mathrm{~cm}$. Setiap petak percobaan diambil sampel sebanyak 12 tanaman untuk pengamatan pertumbuhan dan hasil bawang merah.

Bibit yang digunakan dalam pernelitian ini adalah bawang putih varietas sin Chung. Siung bawang putih dipilih yang utuh, tidak cacat, padat, berukuran 1-3 gram. Lahan yang digunakan sebagai area! cobaan dibersihkan dari rerumputa mudian dicangkul dengan kedalamm kurang lebih $30 \mathrm{~cm}$. Tanah dibersihk ari sisa akar rerumputan dan dibuat oedengan dengan ukuran 1,2 x $1 \mathrm{~m}$ dan kemudian diberi dolomit sebanyak 1,23 ton/ha (147,6 gr/petak) (pH tanah 5,9) dan pupuk kandang 25 ton/ha (3 kg/petak) ditebar pada petak-petak atau bedeng percobaan kemudian diaduk hingga tercampur merata dengan tanah dan dibiarkan selama 2 minggu.

Pemupukan dilakukan sebanyak 2 kali yaitu : pertama saat pengolahan tanah dengan menggunakan pupuk kandang dengan dosis 25 ton/ha (3 kg/petak), 
selanjutnya pada umur 30 hst, tanaman bawang putih diberikan pupuk susulan berupa pupuk NPK (15:15:15:) dengan dosis $600 \mathrm{~kg} / \mathrm{ha}$ (72 gr/petak) dengan cara di larikan disekitar tanaman kemudian ditimbun dengan tanah. Diberikan 30 hari setelah tanam (Lingga dan Marsono, 2013).

Pemasangan mulsa dilakukan 2 minggu setelah pemberian dolomit dan pupuk kandang. Mulsa yang telah dipasang dibuat lobang tanam dengan jarak lobang sesuai dengan jarak tanam bawang putih. Untuk memudahkan dalam pengamatan maka setiap petakan diberi label. Penanaman dilakukan dua minggu setelah pemberian pupuk kandang, Penanaman siung bawang putih menggunakan ukuran yang seragam yaitu 1-3 gr dan ditanam dengan kedalaman 2$3 \mathrm{~cm}$, tiap lubang tanam ditanami dengan satu umbi dengan jarak tanam $10 \times 15$ $\mathrm{cm}$. Umbi dibenamkan sampai ujungnya rata dengan permukaan tanah.

Pemeliharaan yang dilakukan adalah penyulaman dilakukan pada tanaman yang tidak tumbuh secara normal sampai saat berumur 7 hari setelah tanam, dengan menggunakan bibit yang ditanam bersamaan dengan perlakuan dibedengan yang terpisah dari bedengan perlakuan. Penyiraman akan dilakukan dua kali sehari yaitu pagi dan sore hari, dan dilakukan sekali sehari ketika hujan turun dimalam hari, penyiraman akan dihentikan 5 hari menjelang pemanenan agar umbi tidak mudah busuk.

Pada saat menjelang panen, semua kegiatan pengairan dan penyemprotan pestisida dihentikan. Panen bawang putih tergantung pada varietasnya, yaitu pada 93 hari setelah tanam. Ciri-ciri tanaman siap panen adalah terjadi perubahan warna pada daun dari hijau menjadi kuning dengan tingkat kelayuan 35-60\%, umbi penuh dan kompak, sebagian umbi muncul ke permukaan tanah (Sasia, 2016).

Variabel yang diamati dalam penelitian berupa tinggi tanaman $(\mathrm{cm})$, jumlah daun (helai), diameter umbi / tanaman $(\mathrm{cm})$, jumlah siung per umbi (siung), bobot basah umbi per rumpun (g), bobot basah umbi per petak (g), dan bobot kering umbi (ton/ha). Untuk mengetahui pengaruh perlakuaan dari variabel yang diamati, maka dianalisis dengan menggunakan analisis ragam (anova). Apabila berpengaruh nyata maka dilanjutkan dengan uji Ducan Multiple Range Test (DMRT) pada taraf 5\% (Steel and Torrie, 1994).

\section{HASIL DAN PEMBAHASAN}

\section{Tinggi Tanaman (cm)}

Berdasarkan hasil analisis ragam menunjukkan bahwa respon bawang putih terhadap pemberian berbagai mulsa plastik menunjukan pengaruh nyata terhadap tinggi tanaman $(\mathrm{cm})$. Rataan tinggi tanaman bawang putih pada masing-masing perlakuan pengaruh pemberian berbagai mulsa plastik dapat dilihat pada Tabel 1.

Tabel 1. Rataan Tinggi Tanaman Bawang Putih Pengaruh Pemberian Berbagai Mulsa Plastik

\begin{tabular}{cc}
\hline Perlakuan & $\begin{array}{c}\text { Rata-Rata }(\mathrm{cm}) \\
(\mathrm{cm})\end{array}$ \\
\hline M0 & $27,36 \mathrm{~b}$ \\
M1 & $28,74 \mathrm{a}$ \\
M2 & $26,69 \mathrm{~b}$ \\
M3 & $27,15 \mathrm{~b}$ \\
M4 & $28,90 \mathrm{a}$ \\
\hline $\mathrm{KK}=1,79 \%$ & \\
\hline \multicolumn{2}{l}{ Keterangan : Angka-angka yang di ikuti oleh huruf } \\
kecil yang berbeda pada kolom yang \\
sama menunjukkan berbeda nyata \\
menurut uji DNMRT pada taraf 5\%.
\end{tabular}

Tabel 1 menunjukkan bahwa respon tinggi tanaman bawang putih pada perlakuan M0 tidak berbeda secara nyata dengan perlakuan M2 dan M3 tapi 
berbeda dengan perlakuan M1 dan M4. Rataan tinggi tanaman bawang putih paling rendah terdapat pada perlakuan M2 yaitu 26,69 $\mathrm{cm}$ sedangkan rataan tinggi tanaman tertinggi terdapat pada perlakuan M4 yaitu $28,90 \mathrm{~cm}$ dan tidak beda dengan perlakuan M1 sehingga perlakuan M4 merupakan perlakuan terbaik terhadap tinggi tanaman bawang putih.

Perbedaan respon yang ditunjukkan tanaman akibat pemberian mulsa plastik biru (M4) dan mulsa plastik perak (M1) dibandingkan dengan tanpa mulsa (M0), mulsa plastik hitam (M2) dan mulsa plastik transparan (M3) diduga disebabkan oleh mulsa plastik biru (M4) dan mulsa plastik perak (M1) menurunkan suhu tanah yang berperan penting dalam berbagai proses fisiologi dan pertumbuhan tanaman.

Menurut Rukmana (2002), mulsa dapat menaikan suhu tanah pada musim dingin dan menurunkan suhu tanah pada musim kemarau, sehingga sesuai dengan lingkungan yang dibutuhkan tanaman. Sedangkan menurut Paryoga $d k k$., (2016) secara spesifik warna mulsa plastik menentukan suhu udara di permukaan mulsa dan suhu tanah di bawah mulsa. Salisbury dan Ross (1992) menyatakan bahwa suhu mempengaruhi tingkat kelarutan gas karbondioksida, dan semakin tinggi suhu maka kelarutan karbondioksida dalam kloroplas semakin menurun, sehingga mempengaruhi proses fisiologi tanaman.

Penggunaan plastik biru (M4) dan mulsa plastik perak (M1) dapat memodifikasi keseimbangan dari unsur hara dan air yang diperlukan oleh tanaman sehingga pertumbuhan dari perakaran akan baik. Pertumbuhan akar yang baik akan mempengaruhi pertumbuhan tajuk tanaman. Akar akan menyerap air tanah dan unsur hara yang selanjutnya diangkut melalui jaringan xylem menuju organ-organ yang akan mensintesisnya dalam suatu proses yang disebut fotosintesis. Hasil fotosintesis (fotosintat) akan ditranslokasikan ke seluruh jaringan tanaman melalui jaringan floem dan akan bergerak dua arah yaitu ke arah atas dan bawah menuju daerah pemanfaatannya. Pergerakan substansi ke atas akan membantu pertumbuhan tajuk (pucuk dan daun) sehingga tanaman akan lebih tinggi dan jumlah daun akan bertambah (Kusumasiwi dkk., 2011).

\section{Jumlah Daun (Helai)}

Hasil analisis ragam menunjukkan bahwa respon bawang putih terhadap pemberian berbagai mulsa plastik menunjukan pengaruh nyata terhadap jumlah daun (helai). Rataan jumlah daun bawang putih pada masing-masing perlakuan pengaruh pemberian berbagai mulsa plastik dapat dilihat pada Tabel 2 .

Tabel 2. Rataan Jumlah Daun Tanaman Bawang Putih Pengaruh Pemberian Berbagai Mulsa Plastik

\begin{tabular}{cc}
\hline Perlakuan & $\begin{array}{c}\text { Rata-Rata } \\
\text { (helai) }\end{array}$ \\
\hline M0 & $4,84 \mathrm{~b}$ \\
M1 & $5,13 \mathrm{a}$ \\
M2 & $4,84 \mathrm{~b}$ \\
M3 & $4,84 \mathrm{~b}$ \\
M4 & $5,13 \mathrm{a}$ \\
\hline KK =2,48 \% & \\
\hline Keterangan & Angka-angka yang di ikuti oleh huruf \\
\multicolumn{2}{c}{ kecil yang berbeda pada kolom yang } \\
\multicolumn{2}{l}{ sama menunjukkan berbeda nyata } \\
\multicolumn{2}{c}{ menurut uji DNMRT pada taraf 5\%. }
\end{tabular}

Tabel 2 menunjukkan bahwa respon tanaman bawang putih pada perlakuan M0 tidak berbeda dengan perlakuan M2 dan M3 tapi berbeda dengan perlakuan M1 dan M4. Rataan jumlah daun tanaman bawang putih paling rendah terdapat pada perlakuan M0, M2 dan M3 yaitu 4,84 helai sedangkan rataan jumlah daun terbanyak terdapat pada perlakuan M1 dan M4 yaitu 5,23 helai sehingga perlakuan M1 dan 
perlakuan M4 merupakan perlakuan yang sama baik dalam meningkatkan jumlah daun bawang putih. Hal ini karena mulsa plastik biru (M4) dan mulsa plastik perak (M1) mempunyai sifat fisik yang sama yaitu dapat memantulkan kembali radiasi matahari ke atmosfer sehingga dapat mernpertahankan suhu tanah.

Menurut Wisudawati (2016) mulsa plastik perak dapat memantulkan kembali radiasi matahari yang datang sehingga dapat meningkatkan proses fotosintesis serta suhu tanah terjaga. Kandari (2005) juga menyatakan bahwa radiasi surya pada mulsa plastik biru dapat dipantulkan kembali lebih besar ke atmosfer sehingga dapat mernpertahankan suhu tanah dan kelembaban tanah. Mulyatri (2003) menyatakan bahwa aplikasi mulsa merupakan salah satu upaya memodifikasi keseimbangan air, suhu dan kelembaban tanah serta menciptakan kondisi yang sesuai bagi tanaman, sehingga tanaman dapat tumbuh dan berkembang dengan baik. Jella $d k k$, (2017) juga menyatakan bahwa warna perak pada mulsa plastik berdampak pada intersepsi sinar matahari yang lebih optimal sehingga meningkatkan pertumbuhan daun

\section{Diameter Umbi / Tanaman (cm)}

Hasil analisis ragam menunjukkan bahwa respon bawang putih terhadap pemberian berbagai mulsa plastik menunjukan pengaruh nyata terhadap diameter umbi/tanaman $(\mathrm{cm})$. Rataan diameter umbi/tanaman bawang putih pada masing-masing perlakuan pengaruh pemberian berbagai mulsa plastik dapat dilihat pada Tabel 3.

Tabel 3. Rataan Diameter Umbi Pertanaman Bawang Putih Pengaruh Pemberian Berbagai Mulsa Plastik

\begin{tabular}{cr}
\hline Perlakuan & $\begin{array}{r}\text { Rata-Rata } \\
(\mathrm{cm})\end{array}$ \\
\hline M0 & $0,98 \mathrm{~b}$ \\
M1 & $1,06 \mathrm{a}$ \\
M2 & $0,98 \mathrm{~b}$ \\
M3 & $0,97 \mathrm{~b}$ \\
M4 & $1,00 \mathrm{~b}$ \\
\hline $\mathrm{KK}=3,49 \%$ & \\
\hline Keterangan : Angka-angka yang di ikuti oleh huruf \\
kecil yang berbeda pada kolom yang \\
sama menunjukkan berbeda nyata \\
menurut uji DNMRT pada taraf 5\%.
\end{tabular}

Dari Tabel 3 di atas dapat dilihat bahwa respon tanaman bawang putih pada perlakuan M0 tidak berbeda dengan M2, M3 dan M4 tapi berbeda dengan perlakuan M4. Rataan diameter umbi per tanaman bawang putih paling rendah terdapat pada perlakuan M3 yaitu 0,87 $\mathrm{cm}$ sedangkan rataan diameter umbi per tanaman bawang putih terbesar terdapat pada perlakuan M1 yaitu $1,06 \mathrm{~cm}$ dan berbeda dengan semua perlakuan sehingga perlakuan M1 merupakan perlakuan yang terbaik dalam meningkatkan diameter umbi per tanaman bawang putih. Hal ini diduga karena suhu tanah pada mulsa plastik perak (M1) lebih optimal dibandingkan dengan mulsa plastik lainnya (lampiran 7), sehingga diameter umbi lebih besar.

Zainal (2004), menyatakan bahwa pada perlakuan mulsa plastik memiliki albedo yang tinggi menyebabkan sebagian besar radiasi dipantulkan dan hanya sebagian kecil saja yang diteruskan ke lapisan bawahnya sehingga suhu tanah lebih rendah dibandingkan perlakuan tanpa menggunakan mulsa. Lebih lanjut Timlin et al, (2006) menyatakan bahwa suhu tanah yang rendah dapat mengurangi laju respirasi akar sehingga asimilat yang disalurkan untuk penimbunan cadangan bahan makanan menjadi lebih banyak dibandingkan perlakuan tanpa menggunakan mulsa plastik. 


\section{Jumlah Siung / Umbi (Siung)}

Hasil analisis ragam menunjukkan bahwa respon jumlah umbi pertanaman bawang putih terhadap pemberian berbagai mulsa plastik bernilai sama yaitu 1 siung, sehingga rataan jumlah umbi per umbi bawang putih tidak dianalisis lebih lanjut. Untuk lebih jelasnya dapat dilihat pada Tabel 4 sebagai berikut.

Tabel 4. Rataan Jumlah Siung per Umbi Pertanaman Bawang Putih Pengaruh Pemberian Berbagai Mulsa Plastik

\begin{tabular}{rc}
\hline Perlakuan & $\begin{array}{c}\text { Rata-Rata } \\
\text { (buah) }\end{array}$ \\
\hline M0 & 1,00 \\
M1 & 1,00 \\
M2 & 1,00 \\
M3 & 1,00 \\
M4 & 1,00 \\
\hline KK $=0 \%$ & \\
\hline
\end{tabular}

Dari Tabel diatas menunjukan bahwa rataan jumlah siung per umbi bawang putih pengaruh pemberian berbagai mulsa plastik menunjukan pengaruh tidak berbeda yaitu 1 siung. Hal ini diduga karena mulsa yang diberikan lebih cenderung memperbesar umbi, selain itu suhu yang terlalu panas dan penyimpanan siung sebagai bahan tanam juga mempengaruhi pembentukan siung.

Menurut Brewster (2008), suhu penyimpanan umbi selain mempengaruhi kecepatan berkecambah setelah penanaman, vigor pertumbuhan dan bentuk tanaman setelah tumbuh juga mempengaruhi pembentukan pengumbian bawang putih. Lebih lanjut Ainammardliyyah (2018) menyatakan bahwa apabila setelah penanaman, siung bawang putih terpapar suhu tinggi dan hari panjang maka akan mendorong diferensiasi daun lumbung lebih cepat sehingga siung terbentuk sebelum tunas aksilar bercabang dan menghasilkan umbi tunggal.

\section{Bobot Basah Umbi per Rumpun (g)}

Berdasarkan hasil analisis ragam menunjukkan bahwa respon bawang putih terhadap pemberian berbagai mulsa plastik menunjukan pengaruh nyata terhadap bobot basah umbi per rumpun (g). Rataan bobot basah umbi per rumpun bawang putih pada masing-masing perlakuan pengaruh pemberian berbagai mulsa plastik dapat dilihat pada Tabel 5.

Tabel 5. Rataan Bobot Basah Umbi Per Rumpun Bawang Putih Pengaruh Pemberian Berbagai Mulsa Plastik

\begin{tabular}{cc}
\hline Perlakuan & $\begin{array}{c}\text { Rata-Rata } \\
(\mathrm{g})\end{array}$ \\
\hline M0 & $1,93 \mathrm{c}$ \\
M1 & $2,11 \mathrm{a}$ \\
M2 & $1,98 \mathrm{bc}$ \\
M3 & $1,91 \mathrm{c}$ \\
M4 & $2,03 \mathrm{ab}$ \\
\hline $\mathrm{KK}=3,02 \%$ & \\
\hline Keterangan : Angka-angka yang di ikuti oleh huruf \\
\multicolumn{2}{c}{ kecil yang berbeda pada kolom yang } \\
\multicolumn{2}{c}{ sama menunjukkan berbeda nyata } \\
menurut uji DNMRT pada taraf 5\%.
\end{tabular}

Tabel 5 menunjukkan bahwa respon tanaman bawang putih pada perlakuan M0 tidak berbeda dengan perlakuan M2 dan M3 tapi berbeda dengan perlakuan M1 dan M4. Rataan bobot basah umbi per rumpun bawang putih paling rendah terdapat pada perlakuan M3, yaitu 1,91 gram / rumpun dan tidak berbeda dengan perlakuan M0 dan M1, sedangkan rataan jumlah daun terbanyak terdapat pada perlakuan M1 yaitu 2,11 gram / rumpun dan tidak berbeda dengan M4 yaitu yaitu 2,03 gram / rumpun sehingga perlakuan M1 merupakan perlakuan yang sama baik dalam meningkatkan bobot basah umbi per rumpun bawang putih. Hal ini karena mulsa plastik perak (M1) dapat memodifikasi lingkungan yaitu menurunkan suhu tanah, meningkatkan 
kelembaban sehingga bobot basah perumpun meningkat.

Perlakuan mulsa plastik transparan (M3) menghasilkan bobot umbi basah terendah dan tidak beda dengan perlakuan tanpa mulsa (M0), hal ini dikarenakan perlakuan mulsa plastik transaparan dan perlakuan tanpa mulsa menghasilkan suhu udara yang terlalu tinggi (lampiran 8). Suhu yang tinggi tidak dapat menyebabkan fotosintat hasil fotosintesis yang seharusnya ditimbun sebagai cadangan makanan berupa umbi, dialihkan sebagai sumber energi untuk proses respirasi tanaman, sehingga hal ini menyebakan pembentukan umbi menjadi tidak normal. Sesuai dengan pendapat Timlin $d k k$., (2006) yang menyatakan suhu yang tinggi menyebabkan meningkatnya proses respirasi yang berpengaruh pada menurunnya asimilat dan juga mengurangi hasil umbi karena terjadinya penurunan translokasi fotosintat pada pembentukan umbi. Lebih lanjut Usman dan Warkoyo (1993) yang menyatakan rendahnya laju fotosintesis akan diikuti dengan rendahnya laju pertumbuhan dan perkembangan, sehingga hasil yang diperoleh juga rendah.

\section{Bobot Basah Umbi per Petak (g)}

Berdasarkan hasil analisis ragam menunjukkan bahwa respon bawang putih terhadap pemberian berbagai mulsa plastik menunjukan pengaruh nyata terhadap bobot basah umbi per petak (g). Rataan bobot basah umbi per petak pada masing-masing perlakuan pengaruh pemberian berbagai mulsa plastik dapat dilihat pada Tabel 6 .

Tabel 6. Rataan Bobot Basah Umbi Per Petak Tanaman Bawang Putih Pengaruh Pemberian Berbagai Mulsa Plastik

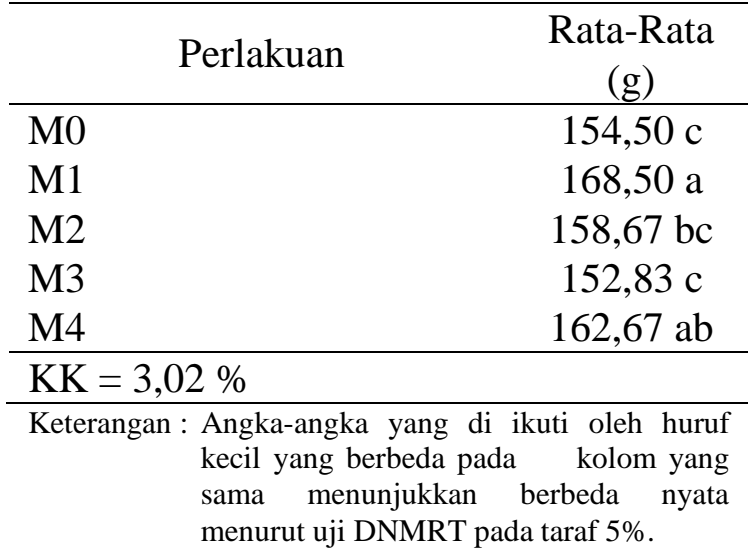

Tabel 6 menunjukkan bahwa respon tanaman bawang putih pada perlakuan M0 tidak berbeda dengan perlakuan M2 dan M3 tapi berbeda dengan perlakuan M1 dan M4. Rataan bobot basah umbi per petak bawang putih paling rendah terdapat pada perlakuan M1, yaitu 152,83 gram / rumpun dan sedangkan bobot basah umbi per petak terberat terdapat pada perlakuan M1 yaitu 168,50 gram/petak dan tidak berbeda dengan M4 sehingga perlakuan M1 merupakan perlakuan yang terbaik dalam meningkatkan bobot basa umbi per petak bawang putih. Hal ini karena mulsa plastik perak (M1) dapat memantulkan kembali radiasi matahari yang datang sehingga suhu tanah terjaga dan bobot basah per petak meningkat. Menurut Timlin dkk., (2006) suhu tanah yang rendah dapat mengurangi laju respirasi akar sehingga assimilat yang dapat disumbangkan untuk penimbunan cadangan bahan makanan menjadi lebih banyak dibanding pada perlakuan tanpa mulsa.

Rata-rata suhu tanah pengaruh perlakuan mulsa plastik perak adalah $30,61^{0} \mathrm{C}$ lebih rendah dari perlakuan lainnya. Menurut Krauss dan Marschsur, (1984) dalam Jella dkk., (2017), pada suhu tanah $30^{\circ} \mathrm{C}$ aktifitas beberapa enzim yang berperan dalam metabolisme pati tertekan, sehingga terjadi penurunan kadar pati pada umbi. Lebih lanjut Samadi (2007), menyatakan 
proses pembentukan umbi sangat dipengaruhi oleh suhu tanah yang rendah pada malam hari yang akan merangsang timbulnya hormon pembentuk umbi pada tanaman. Hormon ini akan diteruskan ke ujung stolon atau bakal umbi.

\section{Bobot Kering Umbi (ton/ha)}

Hasil analisis ragam menunjukkan bahwa respon bawang putih terhadap pemberian berbagai mulsa plastik menunjukan pengaruh nyata terhadap bobot kering umbi (ton/ha). Rataan bobot kering umbi tanaman bawang putih pada masing-masing perlakuan pengaruh pemberian berbagai mulsa plastik dapat dilihat pada Tabel 7.

Tabel 7. Rataan Bobot Kering Umbi Bawang Putih Pengaruh Pemberian Berbagai Mulsa Plastik

\begin{tabular}{lc}
\hline Perlakuan & $\begin{array}{c}\text { Rata-Rata } \\
\text { (ton/ha) }\end{array}$ \\
\hline M0 & $0,90 \mathrm{~b}$ \\
M1 & $0,98 \mathrm{a}$ \\
M2 & $0,92 \mathrm{~b}$ \\
M3 & $0,91 \mathrm{~b}$ \\
M4 & $0,94 \mathrm{ab}$ \\
\hline KK = 3,01 \% \\
\hline Keterangan : Angka-angka yang di ikuti oleh huruf \\
\multicolumn{2}{c}{ kecil yang berbeda pada kolom yang } \\
\multicolumn{2}{c}{ sama menunjukkan berbeda nyata } \\
menurut uji DNMRT pada taraf 5\%.
\end{tabular}

Tabel 7 menunjukkan bahwa respon tanaman bawang putih pada perlakuan M0 tidak berbeda dengan perlakuan M2, M3 dan M4 tapi berbeda dengan perlakuan M1. Rataan bobot kering umbi bawang putih paling rendah terdapat pada perlakuan M0, yaitu 0,90 ton/ha dan sedangkan bobot umbi kering terberat terdapat pada perlakuan M1 yaitu 0,98 ton/ha dan tidak berbeda dengan M4 sehingga perlakuan M1 merupakan perlakuan yang terbaik dalam meningkatkan bobot kering umbi bawang putih. Hal ini karena mulsa plastik perak
(M1) dapat memberikan kondisi lingkungan yang optimal, terutama suhu udara dan suhu tanah yang berperan penting dalam berbagai proses fisiologi (fotosintetis, transpirasi dan respirasi).

Hal ini sejalan dengan pendapat Sembiring (2013), yang menyatakan bahwa warna perak pada mulsa plastik berfungsi untuk memantulkan cahaya matahari, sehingga cahaya yang diterima oleh daun lebih maksimal dan tanaman mampu melangsungkan proses fotosintesis secara optimal. Lebih lanjut Iersel (2003) dalam Wisudawati (2016), bahwa peningkatan suhu hingga batas optimal dapat menaikkan hasil bersih fotosintesis, tetapi pada batas suhu maksimal hasil tersebut menurun tajam karena terjadi peningkatan respirasi. Pada suhu optimum bagi mikroba efektivitasnya meningkat untuk mengurai bahan organik menjadi unsur yang dapat diserap oleh akar tanaman.

Besarnya berat kering umbi pada mulsa plastik perak pada tanaman bawang putih juga tidak lepas dari pertumbuhan tanaman yang baik seperti tinggi tanaman dengan jumlah daun yang lebih baik. Kondisi ini memperlihatkan bahwa translokasi fotosintat berlangsung optimal akibat penyerapan sinar matahari yang optimum oleh tajuk tanaman ditunjang oleh permukaan mulsa plastik yang berwarna perak. Kemampuan tanaman menghasilkan umbi yang lebih besar tidak terlepas dari kemampuan tanaman dalam melakukan fotosintesis. Daun merupakan organ utama tempat berlangsungnya fotosintesis. Oleh karena itu jumlah daun yang optimum memungkinkan distribusi (pembagian) cahaya antar daun lebih merata. Distribusi cahaya yang lebih merata antar daun mengurangi kejadian saling menaungi antar daun sehingga masingmasing daun dapat bekerja sebagaimana mestinya (Sulistyaningsih et al, 2005). 


\section{KESIMPULAN DAN SARAN}

\section{Kesimpulan}

Berdasarkan hasil penelitian dan pembahasan dapat diambil kesimpulan, yaitu sebagai berikut :

1. Respon bawang putih terhadap variabel tinggi tanaman $(\mathrm{cm})$, jumlah daun (helai), diameter umbi/tanaman $(\mathrm{cm})$, bobot basah umbi perumpun $(\mathrm{g})$, bobot basah umbi perpetak $(\mathrm{g})$ dan berat kering umbi (ton/ha) menunjukan respon yang berbeda sementara jumlah siung/umbi (siung) bawang putih sama setiap perlakuan yaitu 1 siung.

2. Respon bawang putih pada perlakuan M1 (Mulsa plastik perak) merupakan perlakuan terbaik terhadap pertumbuhan dan hasil bawang putih (Allium sativum L.).

\section{Saran}

Untuk mendapatkan bawang putih yang maksimal pada pemberian jenis mulsa plastik maka disarankan untuk menggunakan Mulsa plastik perak.

\section{DAFTAR PUSTAKA}

Ainammardliyyah. 2018. Analisis Periode Vernalisasi Terhadap Keragaan Dua Tipe Bawang Putih di Dataran Rendah. Skripsi. IPB. Bogor.

BPS. 2018. Buletin Statistik Perdagangan Luar Negeri (Impor). https://www.bps.go.id. Diunduh 21 Desember 2018

Brewster, J.L. 2008. Onions and Other Vegetable Alliums, 2nd Edition. CAB International, Wallingford, UK
Dirjen Hortikultura, 2018. Produksi, Luas Panen dan Produktivitas Bawang Putih Menurut Provinsi 20132017.

Frona, W.S., Zein A., \& Vauzia. 2016. Pengaruh Penambahan Bokhasi Kubis (Brassica Oleracea Var. Capitata) terhadap Pertumbuhan Bawang Putih (Allium Sativum L) pada Tanah Podzolik Merah Kuning Journal of Sainstek 8(1):10-19. Diunduh 02 Januari 2019

Jella. E.R, A. Suryanto dan L. Setyobudi, 2017. Dampak Aplikasi Mulsa Dan Generasi Umbi Bibit (G2, G3, Lokal) Pada Tanaman Kentang (Solanum tuberosum LINN). Buana Sains Vol 17 No 2. Diuduh 20 Desember 2018.

Kandari. A.M, 2005. Iklim Mikro dan Produksi Cabe Merah (Capsi Annum. L) Pada Lahan Kering Beriklim Kering yang Diberi Berbagai Warna Mı1 n Plastik. Jurnal AGRIPLUS, ne 16 Nomor : 03 Septe $\ldots . . .1$ 2006, ISSN 0854-0128. Diuduh 20 Desember 2018.

Kusumasiwi A.W.P., S. Muhartini dan S. Trisnowati. 2011. Pengaruh Warna Mulsa Plastik Terhadap Pertumbuhan dan Hasil Terung (Solanum melongena L.) Tumpangsari dengan Kangkung Darat (Ipomoea reptans Poir.). Jurnal UGM,Yogyakarta. Diunduh Agustus 2019.

Lingga, P dan Marsono. 2013. Petunjuk Penggunaan Pupuk. Penebar Swadaya Jakarta

Mawardi. 2000. Pengujian Mulsa Plastik pada Tanaman Melon. 
Agrista. 2: 175-180. Diuduh 20 Desember 2018.

Mulyatri. 2003. Peranan pengolahan tanah dan bahan organik terhadap konservasi tanah dan air. Pros. Sem. Nas. Hasil-hasil Penelitian dan Pengkajian Teknologi Spesifik Lokasi.

Prayoga. K.M. 2016. Kajian Penggunaan Mulsa Plastik Dan Tiga Generasi Umbi Bibit Yang Berbeda Pada Komoditas Kentang (Solanum tuberosum L.) Varietas Granola. Jurnal Produksi Tanaman, Volume 4, Nomor 2, Maret 2016, hlm. 137 - 144. Diuduh 22 Desember 2018

Rahayu, M. 2017. Solarisasi Tanah, Salah Satu Alternatif Pengendalian Penyakit Tular Tanah Ramah Lingkungan (Info Teknologi). balitkabi.litbang. pertanian.go.id. Diuduh 22 Desember 2018

Rukmana, R. 2002. Usaha Tani Kentang Sistem Mulsa Plastik. Kanisius. Yogyakarta.

Samadi, B. 2000. Usaha Tani Bawang Putih: Pengembangan Bawang Putih. Kanisius, Yogyakarta

Santoso, H.B. 2000. Bawang Putih. Kanisius, Yogyakarta.

Sarwadana, S.M. dan I.G.A. Gunadi, 2007. Potensi Pengembangan Bawang Putih (Allium Sativum L.) Dataran Rendah Varietas Lokal Sanur. Jurusan Budidaya Pertanian Fakultas Pertanian Universitas Udayana.Agritrop 26: 19 -23. Diuduh 22 Desember 2018
Sasia, A.N . 2016. Pengaruh waktu Pembenaman pupuk hijau dan aplikasi pupuk organik cair terhadap Ppertumbuhan dan hasil bawang putih siung tunggal (Allium sativum, L.) PJU. Savana Cendana.1: 81-84. Diuduh 22 Desember 2018.

Sembiring, A. P. 2013. Pemanfaatan Mulsa Plastik Hitam Perak (MPHP) dalam Budidaya Cabai (Capsicum annuL). http://www.scribd.com/doc/82000 378 /Pemanfaatan-Mulsa-PlastikHitam-Perak-MPHP-DalamBudidaya-Cabai-Capsicumannum-L. Diakses pada 22 Desember 2018

Steel, R.G.D. dan J. H. Torrie, 1994. Prinsip dan Prosedur Statistika (Pendekatan Biometrik) Penerjemah B. Sumantri. Gramedia PustakaUtama. Jakarta.

Sulisbury, F.B. dan C.W. Ross, 1992. Fisiologi Tumbuhan. ITB Bandung.

Sulistyaningsih E, B. Kurniasih dan E, Kurniasih. 2005. Pertumbuhan dan Hasil caisin pada berbagai Warna Sungkup Plastik. Jurnal Ilmu Pertanian 12(1):65-76.

Timlin, D., S.M.L. Rahman., J.Baker., V.R Reddy., D. Fheisher and B. Quebe-deaux. 2006. Whole Plan Photosyn-thesis, Development, and Carbon Partitioning In Potato as Function of Temperature. Agronomi Jurnal.98(5) 11951203. 
Tinambunan, E. 2014. Penggunaan Beberapa Jenis Mulsa Terhadap Produksi Baby Wortel (Daucus carota L.) Varietas Hibrida. Jurnal Produksi Tanaman, Volume 2, Nomor 1, Januari 2014. Diunduh pada 24 Desember 2018.

Usman, \& Warkoyo. 1993. Iklim Mikro Tanaman. Malang: IKIP Malang

Wibowo, S. 2007. Bawang Putih, Bawang Merah dan Bawang Bombay. Penebar Swadaya. Jakarta.

Wisudawati. D, M. Anshar dan I. Lapanjang. 2016. Pengaruh Jenis Mulsa Terhadap Pertumbuhan Dan Hasil Bawang Merah (Allium ascalonicum Var. Lembah Palu) Yang Diberi Sungkup. e-J. Agrotekbis 4 (2) :126-133, April 2016 ISSN : 2338-3011. Diunduh pada 24 Desember 2018.

Zainal, E. 2004. Efek Penggunaan Berbagai Warna Mulsa Plastik Pada Iklim Mikro, Ukuran Umbi dan Produksi Tanaman Kentang var. Granul. Tesis. Sekolah Pascasarjana. Institut Pertanian Bogor. Bogor. 